"نشر يه علوم زراعى ايران"

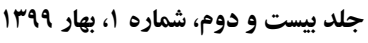

مقاله يخوهشى

اثر كم آبيارى بر عملكرد دانه و اجزاى عملكرد هيبريدهاى آفتابكردان (Helianthus annuus L.)

Effect of deficit irrigation on seed yield and yield components of sunflower

(Helianthus annuus L.) hybrids

اسداله زارعى سياه بيدى'، عباس رضايى زادّ جهانفر دانشيانr

جكيده

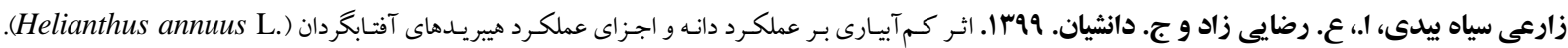
نشريه علوم زراعى ايران. بr(1): عا-1.

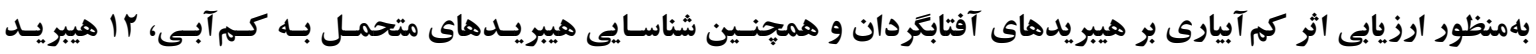

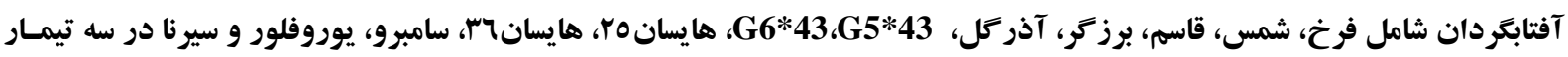

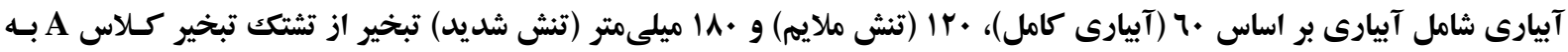

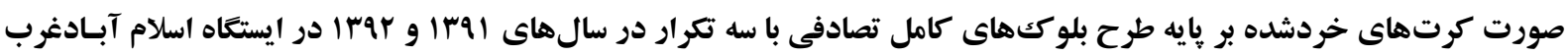

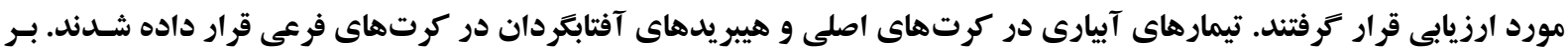

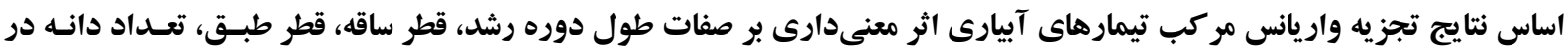

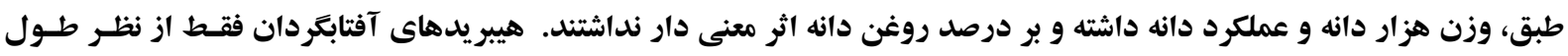

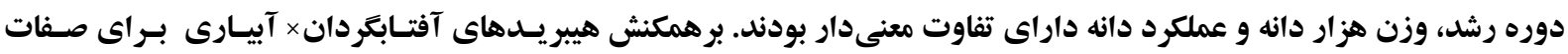

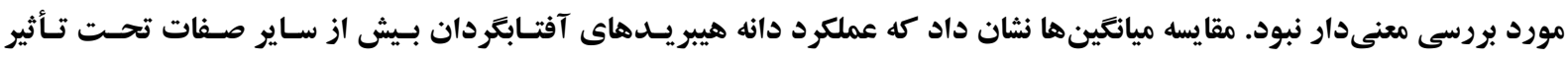

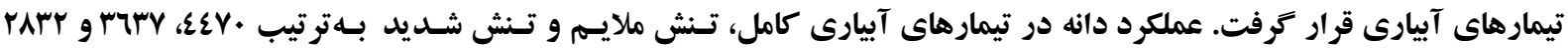

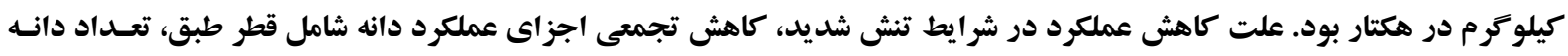

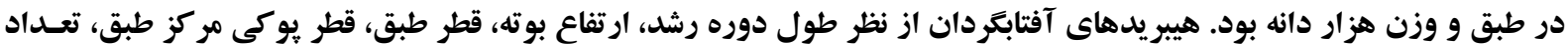

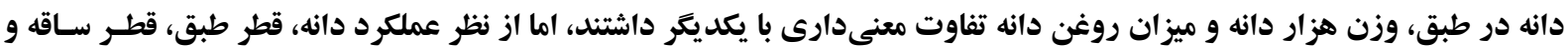

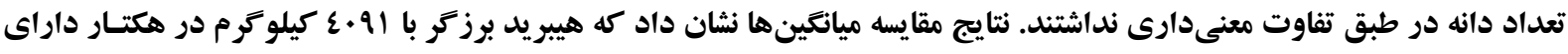

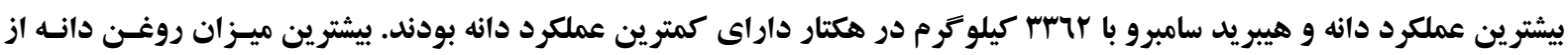

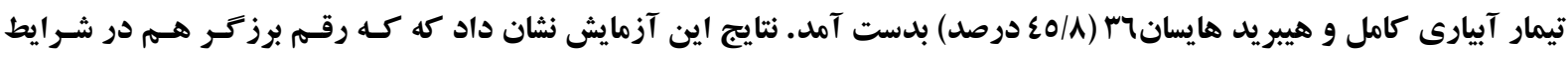

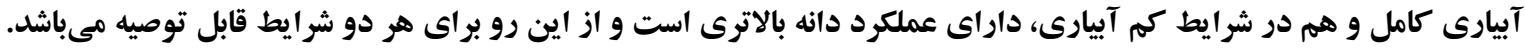

وازههاى كليدى: آفتابكردان، تنش خشكى، روغن دانه، قطر طبق و هيبريد.

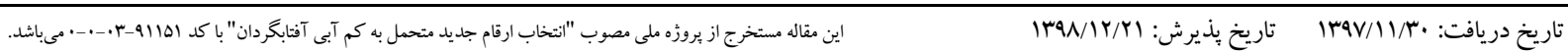

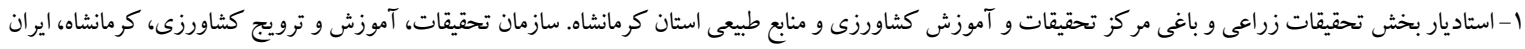
(مكاتبه كننده) (بست الكترونيكك: (azareei46@gmail.com)

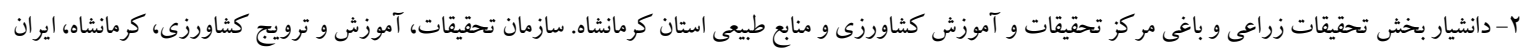

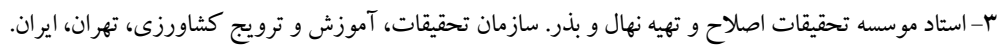


تحقيـق نظامى و همكـاران (Nezami et al., 2008) در

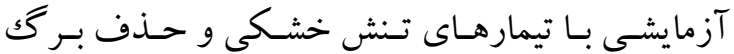

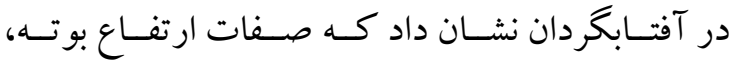
مـاده خشـك گيـاه، قطر طبـق، قطر سـاقه، تعـداد دانسه

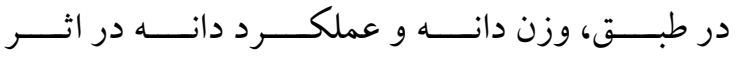

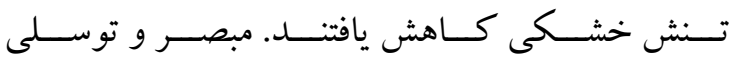
(Mobasser and Tavasolli, 2013)

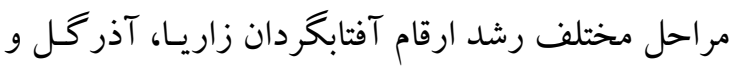

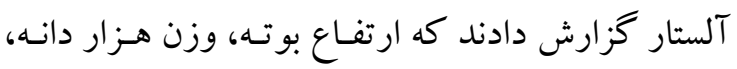

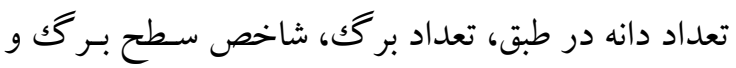

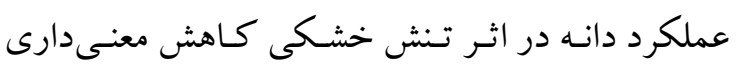
داشتند. به غير از مناطق شمال كشور كـهـ بـه دليـل بـارش در فصل هاى مختلف سال، امكـان كشـت انسواع كياهـان را بدون آبيـارى ميسـر مسىسـازد، در سـاير منـاطق كشـور

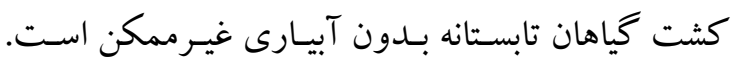

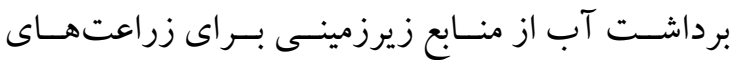

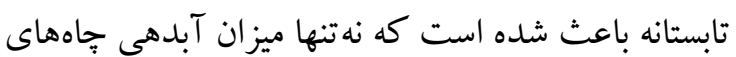
آب در بسيارى از مناطق كاهش يابد، بلكه باعث تشديد

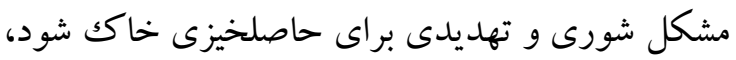

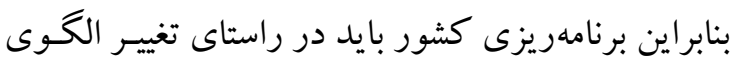
كشـت بـه سـمت توسـعه كشـت كياهـانى باشـــ كـه در

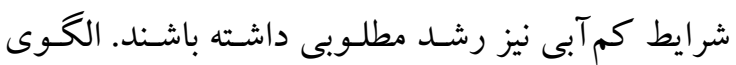

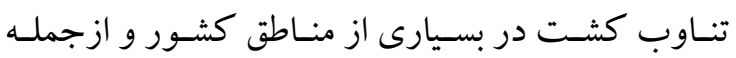
استان كرمانشاه بهصورت كندم- ذرت است. نياز بـالاى

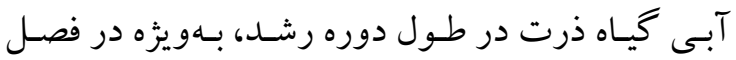

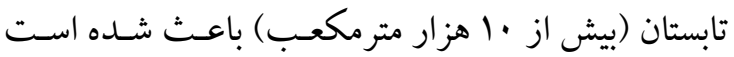

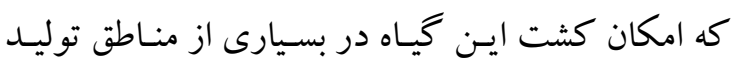
محدود شود. با اين حسال در صسورتى كه كيـاه جـايكزين

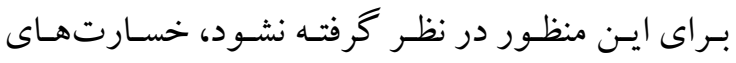

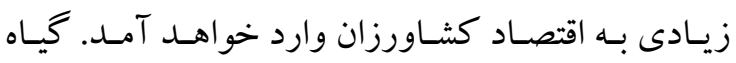
آفتابكردان مى تواند بهعنوان يكك گياه جايخزين مناسب در الكوى كشت جنين منـاطقى مطرح شـود. از ايـنرو تحقيق حاضر با هدف شناسايى زُنوتيبٍهای آفتابكردان

\section{مقدمه}

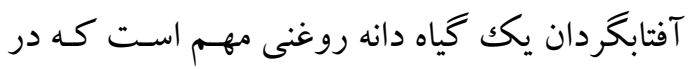

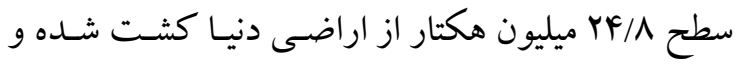

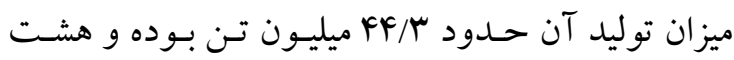

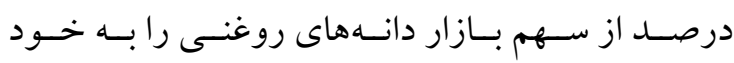

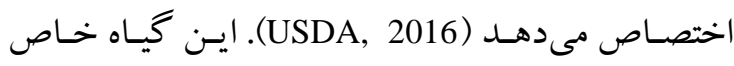

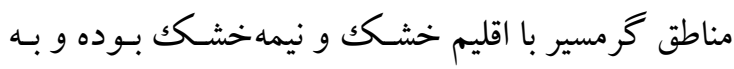
صورت ديم و يا بـا آبيـارى تكميلـى كشـت مسى شـود و

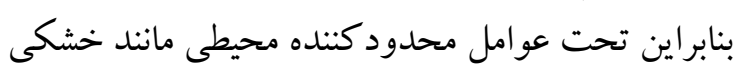
و دما قرار مى گيرد (Robert et al., 2016). تنش خشكى يكى از مهم ترين عوامل محدود كنتــده

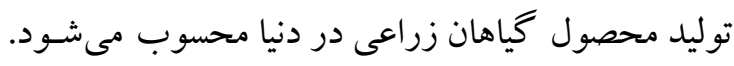

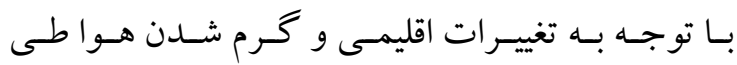

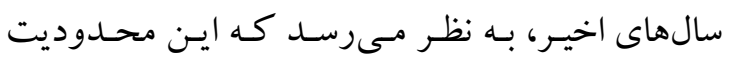

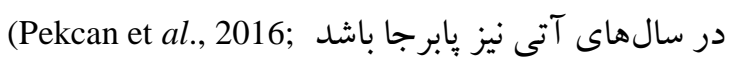
تمussain et al., 2018) توانايى جذب آب از لايههاى عميقتر خاكك، يك گياه

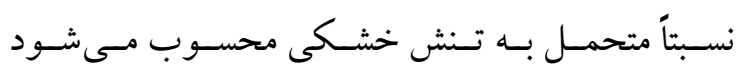

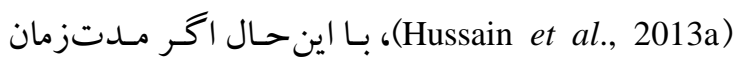
تنش خشكى طـولانى شـود، باعث اثـر منفى بـر كيـاه

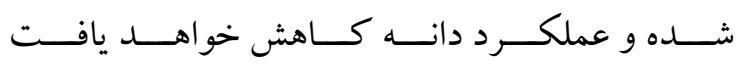
(Andrianasolo et al., 2014)

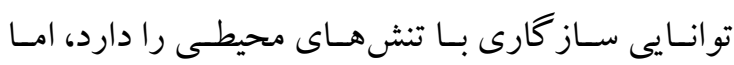

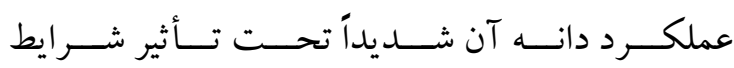

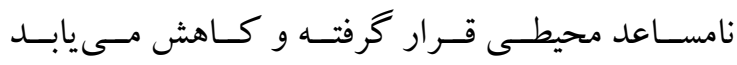
(Krizmanić et al., 2012)

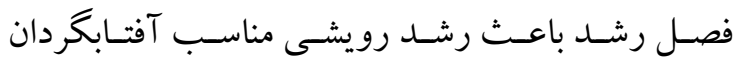

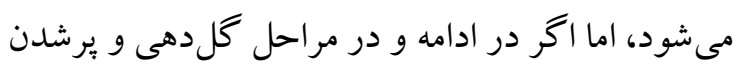

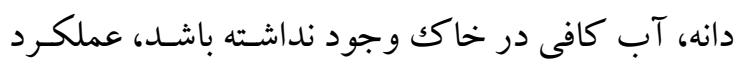

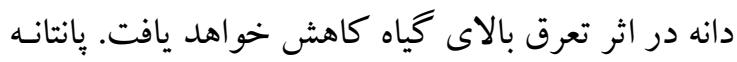

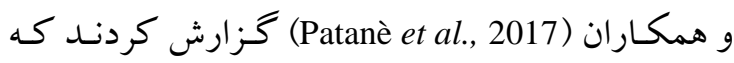
بيشترين عملكرد دانه آفتابكردان از تيمار آبيـارى كامـل

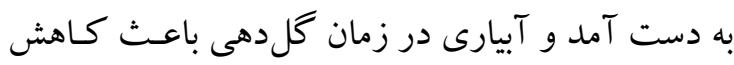
معنى دار اثر تنش خشكى در گياه آفتابكردان شد. نتسايج 
سال آزمايش هفته اول خرداد بود. ميزان كـود بـا توجـه

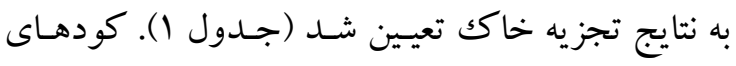

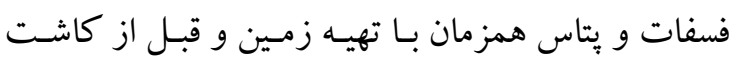

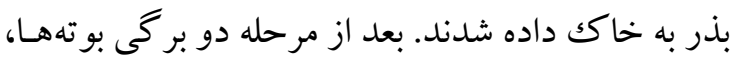

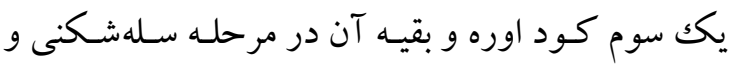

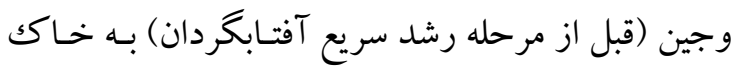

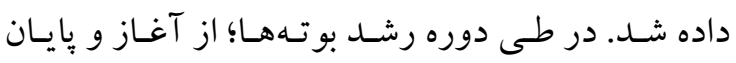

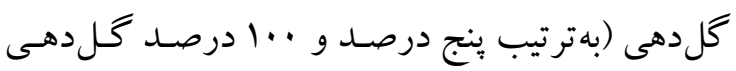

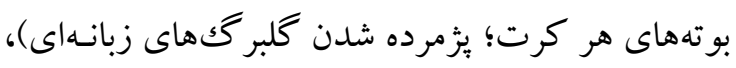

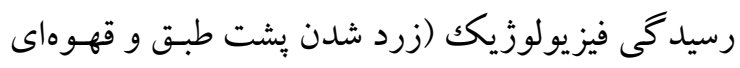

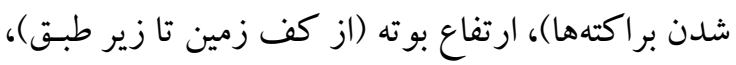

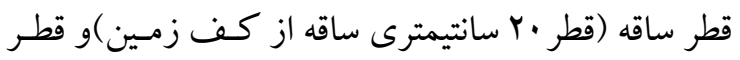

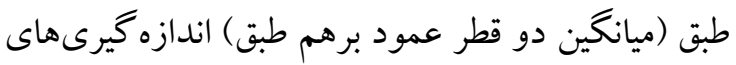

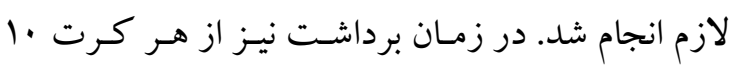

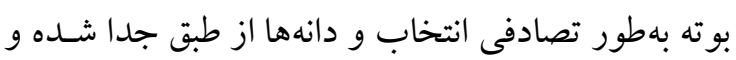

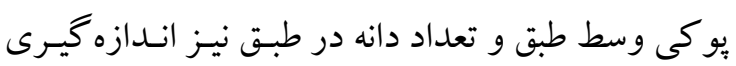

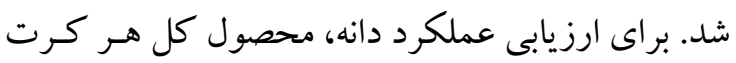

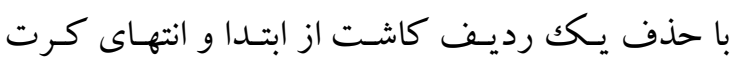
برداشت و دانهها توزين شدند. وزن هزار دانه بـر اسـاس

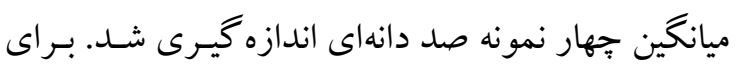

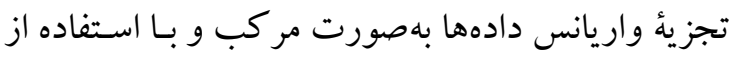

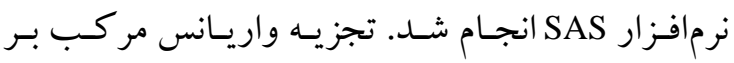

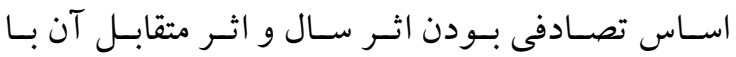
هيبريدهاى آفتابخر دان و رزيم آبيارى و ثابت بـودن اثر انـر

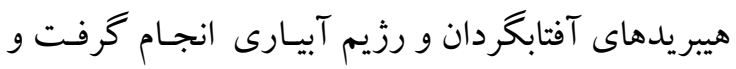
ايسن موضـوع در مخـرج آزمسون F در تجزيـه واريـانس

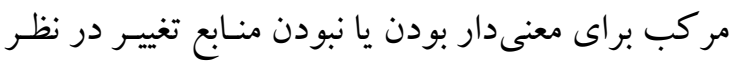
كرفته شد. براى بررسى يكنـواختى واريـانس اشـتباهات آزمايشـى از روش Fmax هــارتلى (Hartley's Fmax)

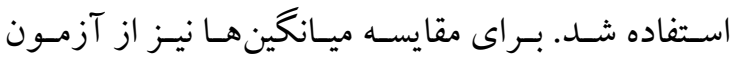
اختلاف معنىدار حقيقى توكى استفاده شد.

\section{نتايج و بحث}

بر اساس نتايج آزمـون Fmax، يكنـواختى اشـتباهات
متحمل به تنش خشكى و ارزيابى اثـر تسنش خشكى بـر

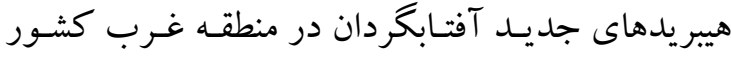

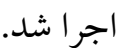

\section{مواد و روشها}

بهمنظور ارزيابى خصوصيات زراعى و عملكرد دانـه

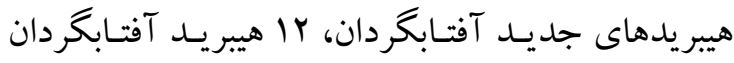

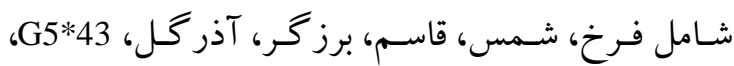

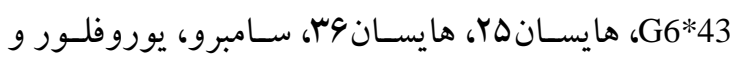

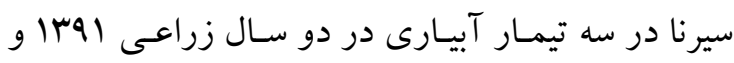

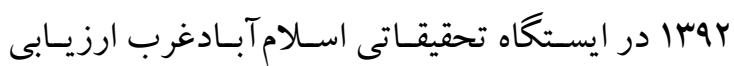

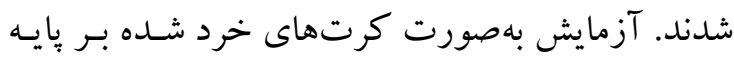

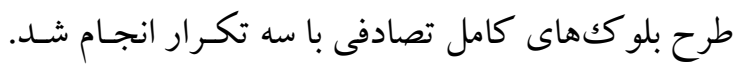

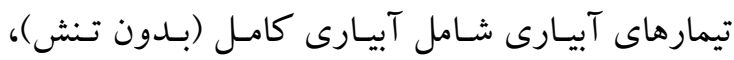

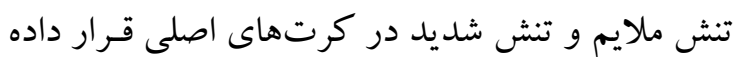

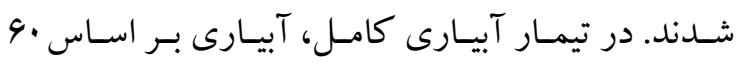

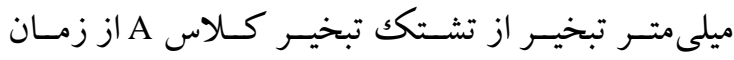

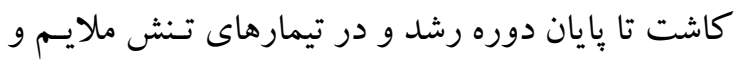

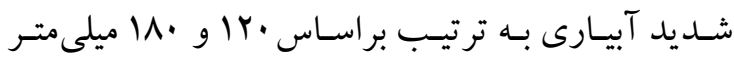

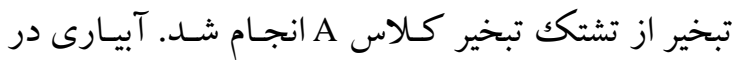

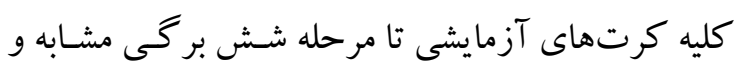

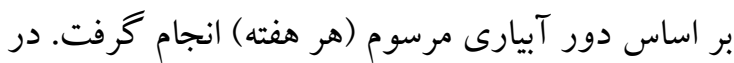

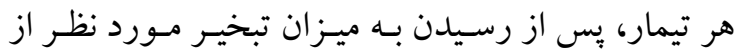

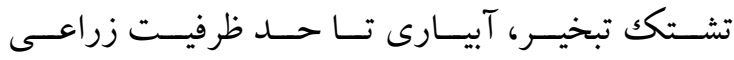

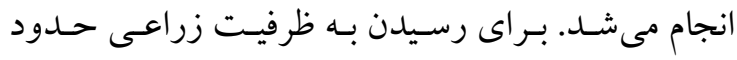

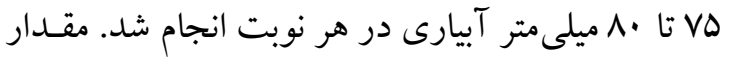
آب آبيارى با در نظر كرفتن فشار سيستم آبيارى، تعـداد آب بِاشها در واحـد سـطح و سـاعات آبيـارى متـداول بدست آمد. تعداد كل دفعات آبيارى از ابتـدا تـا انتهاى

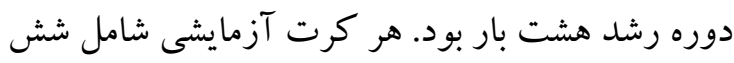
خط كاشت شش مترى با فاصـله •9 سـانتى متر و فاصـله

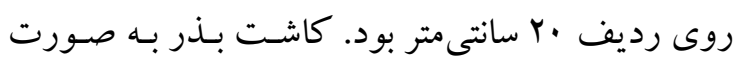

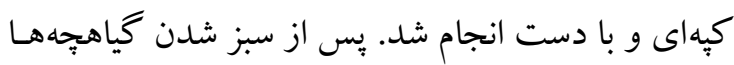

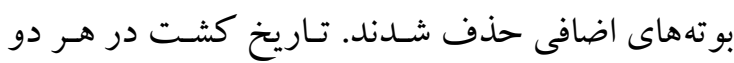


"نشريه علوم زراعى ايران"، جلد بيست و دوم، شماره 1، بهار 99سا

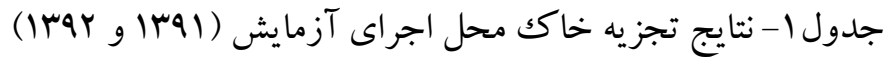

Table1. Result of soil analysis at experiment site (2011 and 2012)

\begin{tabular}{lccc}
\hline & & |ra| & |rar \\
& 2011 & 2012 \\
\hline Organic carbon (\%) & 1.03 & 1.08 \\
Phosphorous (mg.kg-1) & كربن 28.2 & 37 \\
Potassium (mg.kg-1) & 718 & 744 \\
\hline
\end{tabular}

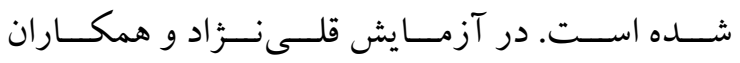
كزارش شد كه با افزايش (Gholinezhad et al., 2012) شدت تنش خشكى، سرعت بر شدن دانه افزايش يافته و

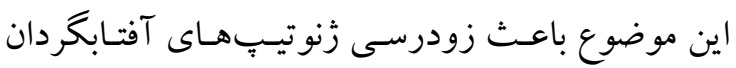

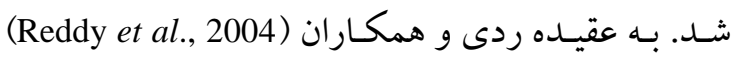

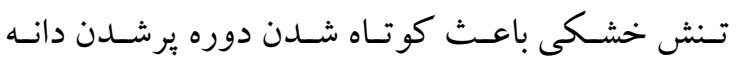

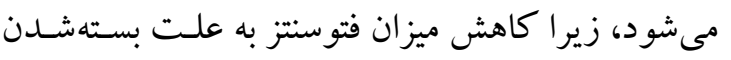

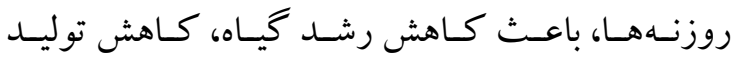

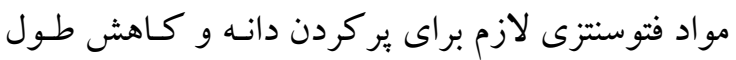

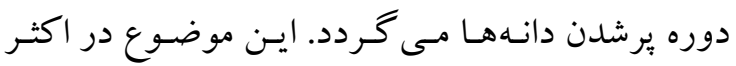
كياهان زراعى صادق است، از جملـه اوكك و همكـاران (Ouk et al., 2003) برنج باعث افزايش سرعت بر شدن دانه شـــ و بـا تـأمين

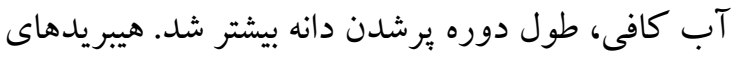
آفتابكردان مورد بررسى از نظر طول دوره رشد تفـاوت معنى دارى با يكديخر داشتند، ولى بـرهمكنش آنس آنهـا بـا

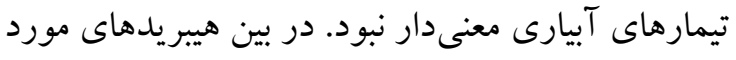

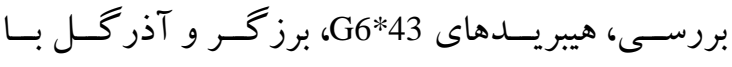

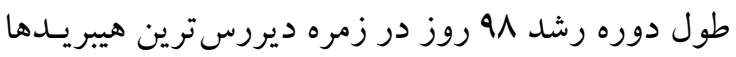

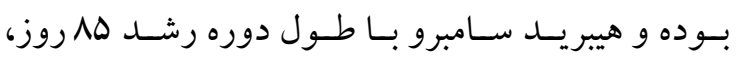

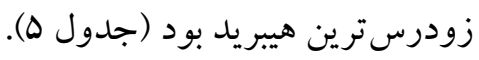

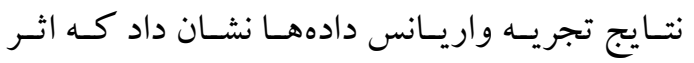
تيمارهاى آبيارى و اثر هيبريد بر ارتفاع بوته در دو سـال

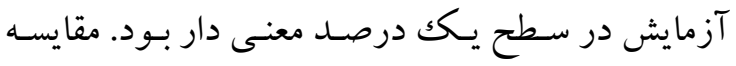

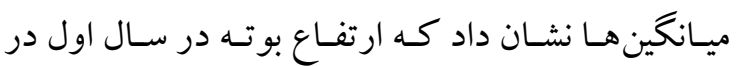
شر ايط تنش شديد \&/V درصد و در شر ايط تنش ملايم

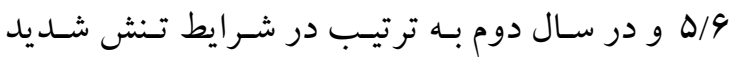

آزمايشى براى صـفات ارتفـاع بوتـه و قطر يـوكى طبـق

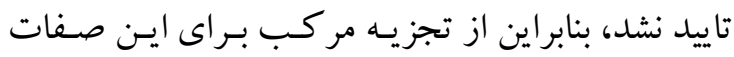

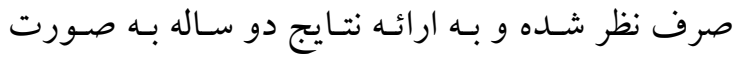

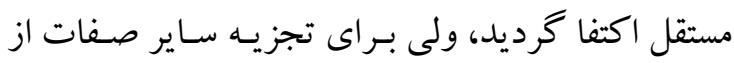

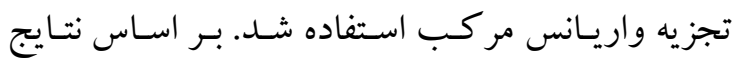

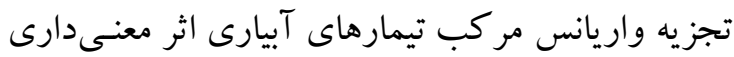
بر صفات طول دوره رشد، قطر ساقه، قطر طبق، تعـداد

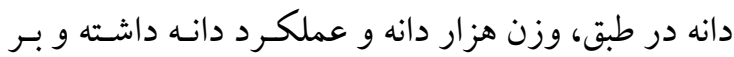
ميزان روغن دانه اثر معنىدارى نداشتند. بر اساس نتسايج

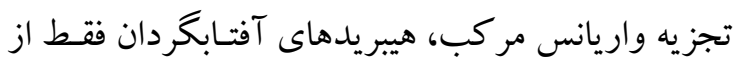

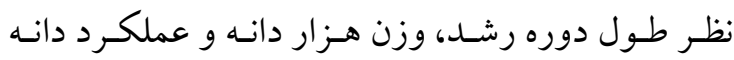
داراى تفاوت معنىدارى بودند. بـرهمكنش هيبريـدهاى

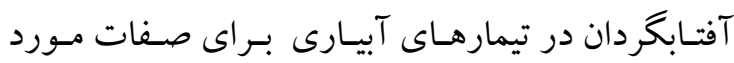
بر رسى معنى دار نبود. نتايج تجزيه واريانس ساده ارتفـاع

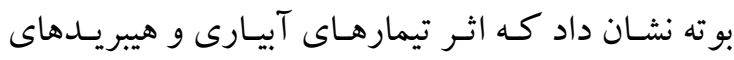

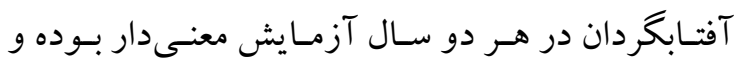
براى صفت قطر يوكى طبتق، اثر تيمارهـاى آبيـارى در

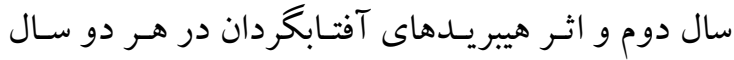

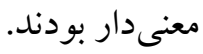

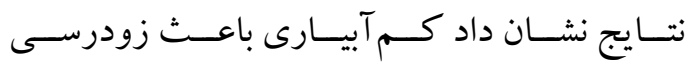

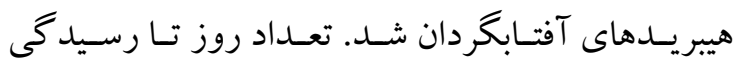
فيزيولوزيكك در تيمارهاى آبيارى كامل، تـنش ملايسم و

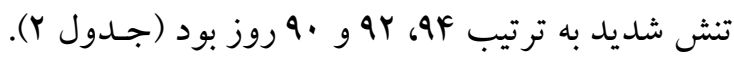

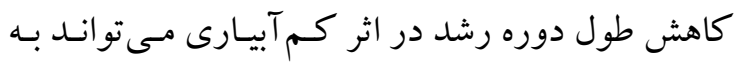
دليل كاهش طول مدت كل كدهى و يا طول دوره برشدن آند

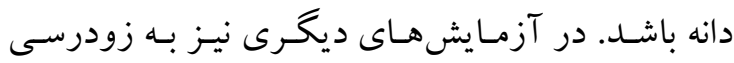

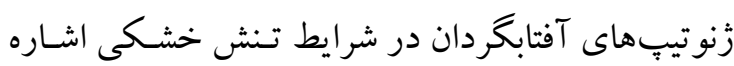




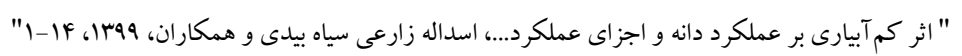

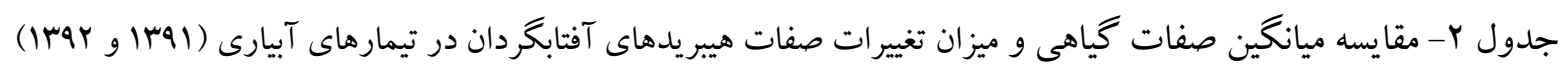

Table 2. Mean comparison of plant traits and changes of traits of sunflower hybrids in irrigation treatments (2011-2012)

\begin{tabular}{|c|c|c|c|c|c|c|c|}
\hline Treatments تيمارهاى آزمايشى & $\begin{array}{c}\text { روز تا رسيدگى } \\
\text { Days to maturity }\end{array}$ & $\begin{array}{c}\text { قطر ساقه } \\
\text { Stem diameter (mm) } \\
\end{array}$ & $\begin{array}{c}\text { قطر طبق } \\
\text { Head diameter (cm) } \\
\end{array}$ & $\begin{array}{l}\text { تعداد دانه در طبق } \\
\text { Seed.head }\end{array}$ & $\begin{array}{c}\text { وزن هزار دانه } 1000 \text { Seed weight (g) } \\
\end{array}$ & $\begin{array}{c}\text { روغن دانه } \\
\text { Oil content of seed (\%) } \\
\end{array}$ & $\begin{array}{c}\text { عملكرد دانه } \\
\left.\text { Seed yield (kg.ha-1 }{ }^{-1}\right) \\
\end{array}$ \\
\hline Full irrigation & 94.4 & 19.9 & 16.2 & 928 & 65.5 & 42.1 & 4470 \\
\hline Mild stress & 91.9 & 17.0 & 15.1 & 795 & 61.4 & 40.1 & 3637 \\
\hline $\begin{array}{l}\text { درصد تغيير نسبت به آبيارى كامل } 1 \% \text { (\%) } \\
\text { Changes compare to full irrigation }\end{array}$ & 2.6 & 14.6 & 6.8 & 14.3 & 6.2 & 2.8 & 18.6 \\
\hline Severe stress & 90.4 & 14.1 & 14.5 & 660 & 58.1 & 39.4 & 2832 \\
\hline $\begin{array}{l}\text { درصد تغيير نسبت به آبيارى كامل } 1 \% \text { (\%) } \\
\text { Changes compare to full irrigation }\end{array}$ & 4.2 & 29.1 & 10.5 & 28.9 & 11.3 & 6.6 & 36.6 \\
\hline $\mathrm{HSD}(\mathrm{p} \leq 0.05)$ & 1.3 & 7.1 & 0.11 & 76.2 & 5.4 & 3.7 & 840.1 \\
\hline
\end{tabular}




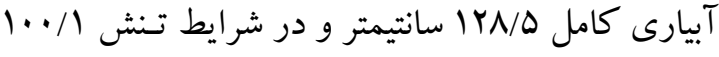

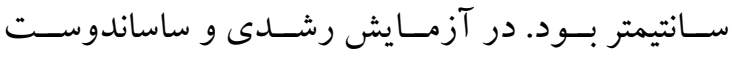

(Roshdi and Sasandoost, 2004)

صفات زراعى جهار زُنوتيب آفتـابكردان مـورد بررسى قرار كرفت. نتـايج نشـان داد كـه ميـانخين ارتفـاع بوتسه

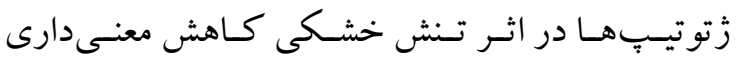
داشت، بهطورى كه در تيمار آبيارى يس از •و ميلىمتـر تبخير از تشتكك تبخير، ها Y سانتيمتر و در تيمـار آبيـارى

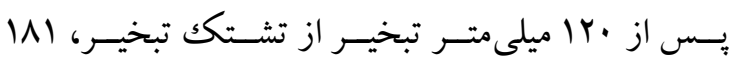
سانتى متر بود.

مقايسه ميانگين ها نشان داد كه قطر ساقه هيبريـدهاى

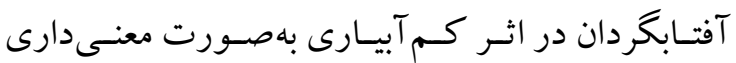
كاهش يافت و در تيمارهاى آبيارى كامل، تسنش ملايسم

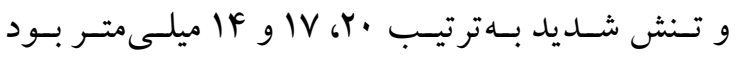
(جــدول Y). قطر سـاقه بـه لحـاظ ذخيـره مـواد يـرورده در طـول دوره رويشـى و امكـان انتقـال ايسن مـواد بــهـ دانهها در مرحله يرشدن، نقش مهمى داشـته و هـر قـدر قطر ساقه بيشتر باشـــ، يتانسـيل توليـد محصـول در گيـاه

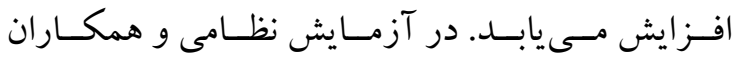
كـزارش شـد كـه در اثـر تـنش (Nezami et al., 2008) خشكى، قطر ساقه آفتابكردان كاهش يافت، بهطورى كه

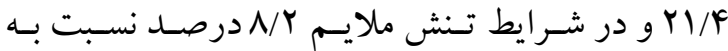

$$
\begin{aligned}
& \text { آبيـارى كامـل كـاهش داشـت (جـدول ب). بـرهمكنش } \\
& \text { هيبريد در آبيـارى در سـال دوم در سـطح يـك درصــ } \\
& \text { معنى دار بود. مقايسه ميـانگينهـا نشـان داد كـه در سـال } \\
& \text { اول هيبريد G6*43 و يوروفلور به ترتيب بـا 191 و } 191 \\
& \text { سـانتيمتر داراى بيشـترين ارتفــاع بوتسه بـوده و كمتـــين } \\
& \text { ارتفــاع بو تـه مربـوط بـه هيبر يــدهاى يوروفلـور، قاسـم و } \\
& \text { برز }
\end{aligned}
$$

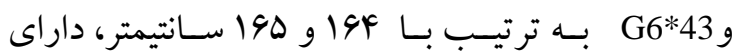

$$
\begin{aligned}
& \text { بيشترين ارتفاع بو ته بوده و هيبريد قاسم با FF ا سـانتيمتر } \\
& \text { در مرتبه آخر قـرار كرفت (جــول F). ارتفـاع بوتـه از } \\
& \text { صـفاتى اسـت كـه اثـر تــش خشـكى بـر آن از طريـق }
\end{aligned}
$$

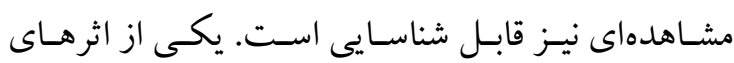

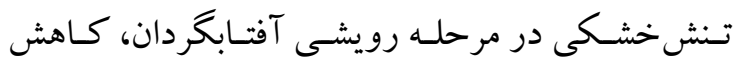

$$
\begin{aligned}
& \text { ميز ان فتوسنتز بـه دليـل كـاهش سـطوح فتوسـنتزى و در }
\end{aligned}
$$

\begin{tabular}{|c|c|c|c|c|}
\hline \multirow[b]{3}{*}{ Treatments } & \multicolumn{2}{|c|}{$\begin{array}{c}\text { ارتفاع بوته } \\
\text { Plant height (cm) }\end{array}$} & \multicolumn{2}{|c|}{$\begin{array}{c}\text { قطر يوكى طبق } \\
\text { Unfilled diameter of head (cm) }\end{array}$} \\
\hline & $|r q|$ & Irar & $|r q|$ & irar \\
\hline & 2011 & 2012 & 2011 & 2012 \\
\hline Full irrigation & 156.5 & 161.3 & 2.2 & 1.7 \\
\hline Mild stress & 147.7 & 148.0 & 2.7 & 2.67 \\
\hline $\begin{array}{r}\text { درصد تغيير نسبت به آبيارى كامل } 1 \% \text { (\%) to full irrigation } \\
\text { Changes compare to }\end{array}$ & 5.6 & 8.2 & 6.9 & -57.0 \\
\hline Severe stress & 133.4 & 126.8 & 2.9 & 3.7 \\
\hline $\begin{array}{l}\text { درصد تغير نسبت به آبيارى كامل } 1 \% \text { (\%) } \\
\text { Changes compare to full irrigation }\end{array}$ & 14.7 & 21.4 & 24.1 & -117.0 \\
\hline $\operatorname{HSD}(p \leq 0.05)$ & 8.4 & 3.72 & 1.15 & 0.63 \\
\hline
\end{tabular}

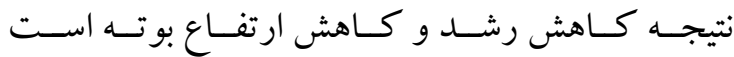

$$
\begin{aligned}
& \text { (Daneshian and Jabbari, 2009). در آزمايش طباطبايى } \\
& \text { و همكـاران (Tabatabei et al., 2012)، قطع آبيـارى در لـ }
\end{aligned}
$$

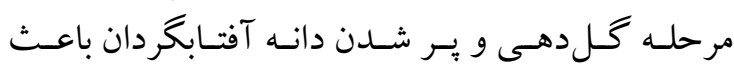

$$
\begin{aligned}
& \text { كاهش معنى دار ارتفاع بوتـه شـد، بهطورى كـه ميـانگين }
\end{aligned}
$$

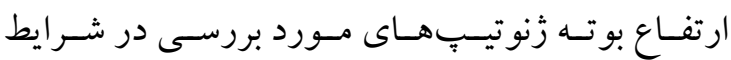

جدول ب- مقايسه ميانگين ارتفاع بوته و قطر يوكى طبق و ميز ان تغييرات صفات هيبريدهاى آفتابكردان در تيمارهاى

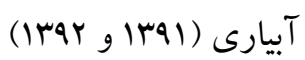

Table 3. Mean comparison of plant height and unfilled diameter of head and and changes of traits of 


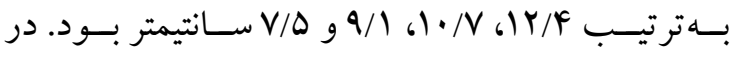

آزمايش طباطبايى و همكاران (Tabatabei et al., 2012) نيز قطر طبق بهعنوان مهم ترين عامـل تعيين كنتـده تعـداد دانه، در اثر تنش خشكى كاهش يافت. نتايج تجريه واريانس دادهها نشان داد كه اثر هيبريـــ در هر دو سال آزمايش و اثر تيمارهاى آبيـارى فقـط در

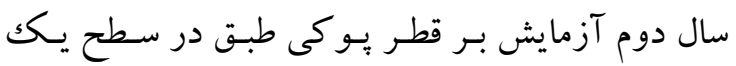
درصد معنى دار بود. مقايسه ميانكينها نشـان داد كـه بـا افزايش شدت تـنش، قطر يـوكى طبـق در هـر دو سـال آزمايش افزايش يافت، بـهـورى كـه در سـال اول قطر يسو كى در شـرايط آبيـارى كامـل، تـنش ملايسم و تسنش شديد به ترتيب Y/Y ، Y و و Y/9 سانتيمتر بود و در سـال

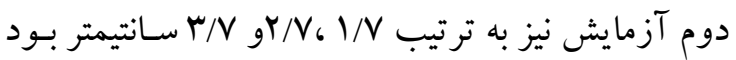
(جـدول r). مقايسـه ميـانكين هـا نشـان داد كـه بيشـترين افزايش قطر يوكى در سال دوم آزمايش مربوط به تسنش شديد بود كه نسبت به آبيارى كامل، IVV درصد بيشـتر بود و در همين سال قطر يـو كى در شـرايط تسنش ملايسم

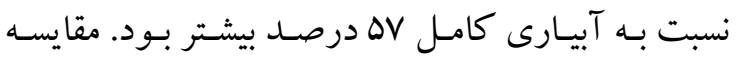

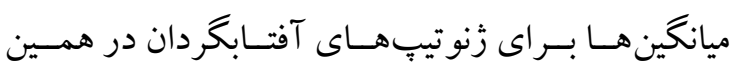

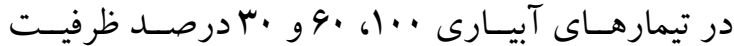

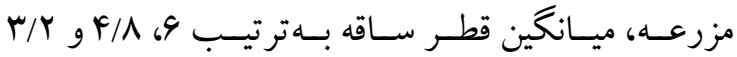
سـانتيمتر بـود. علسىرغــماينكـه هيبريسـدهاى آفتـابكردان ازنظر ارتفاع بوته و طول دوره رشـد تفـاوت معنى دارى داشتند، اما از نظر قطر ساقه تفاوت معنى بدارى بـين آنها مشاهده نشد. برهمكنش هيبر يـدها بـا تيمارهـاى آبيـارى نيز براى اين صفت معنىدار نبود. نتايج واريانس نشان داد قطر طبق در اثر كـمـي آبيـارى كاهش يافت. ميانگين قطر طبق هيبريـدهاى آفتـابكردان در شرايط آبيارى كامل، تنش ملايسم و تـنش شـديد بـهـ

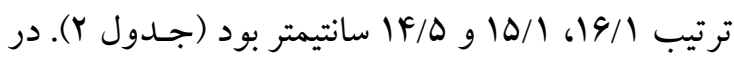
آزمـايش فـررز و همكــاران (Fereres et al., 1986) كـاهش تعـداد دانـه در طبـق در شـرايط تسنش خشكى به كـاهش قطر طبـق و افززايش درصـد يـو كى دانسهــا

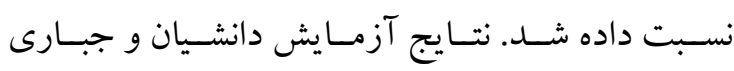
(Daneshian and Jabbari, 2009) طبق آفتابكردان در اثر تنش خشكى بـهـور معنى دارى كاهش يافت و در سطوح مختلف تنش شامل •له، +. •ا و و . . ميلى متر تبخير از تشـتك تبخيـر، قطر طبـق

جدول F- مقايسه ميانگين ارتفاع بوته و قطر يوكى طبق هيبريدهاى آفتابگر دان در تيمارهاى آبيارى ( اqسا و Yqسا)

Table 4. Mean comparison of plant height and unfilled diameter of head of sunflower hybrids in irrigation

\begin{tabular}{|c|c|c|c|c|c|}
\hline & & \multicolumn{2}{|c|}{$\begin{array}{c}\text { ارتفاع بوته } \\
\text { Plant height (cm) }\end{array}$} & \multicolumn{2}{|c|}{$\begin{array}{c}\text { قطر يو كى طبق } \\
\text { Unfilled diameter of head (cm) }\end{array}$} \\
\hline \multirow{2}{*}{\multicolumn{2}{|c|}{$\begin{array}{l}\text { هيبريدهاى آفتابخر دان } \\
\text { Sunflower hybrids }\end{array}$}} & $|129|$ & Irar & $|r a|$ & irar \\
\hline & & 2011 & 2012 & 2011 & 2012 \\
\hline Farrokh & فرخ & 136.4 & 141.9 & 1.8 & 2.2 \\
\hline Shams & شمس & 152 & 150.8 & 1.3 & 2.0 \\
\hline Ghasem & قاسم & 131.4 & 123.5 & 1.7 & 2.4 \\
\hline Barzegar & برزگر & 131.9 & 155.4 & 1.5 & 2.6 \\
\hline $\mathrm{G} 5 * 43$ & & 151.2 & 153.4 & 4.3 & 2.8 \\
\hline G6*43 & & 167.7 & 164.7 & 2.9 & 3.3 \\
\hline Hysun25 & & 144.2 & 145.7 & 2.7 & 2.2 \\
\hline Euroflor & & 160.6 & 124.1 & 4.2 & 3.4 \\
\hline Hysun36 & & 140.2 & 144.2 & 3.3 & 3.7 \\
\hline Azargol & آذرگل & 157 & 164.1 & 3.4 & 2.5 \\
\hline Sumbro & & 132.3 & 132.5 & 1.5 & 2.5 \\
\hline Sirena & & 145.4 & 144.3 & 2.4 & 2.7 \\
\hline $\operatorname{HSD}(\mathrm{p} \leq 0$ & & 15.3 & 7.6 & 2.7 & 0.9 \\
\hline
\end{tabular}


باعـث كــاهش منــابع فتوسـنتزى و كــاهش فعاليـت

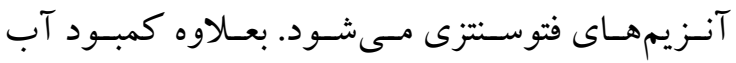

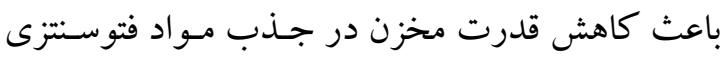

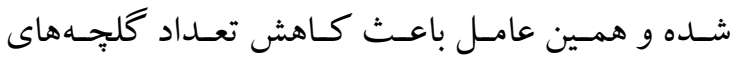

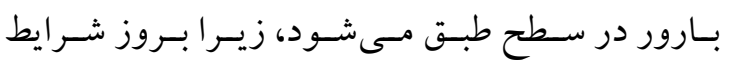

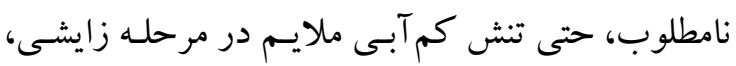

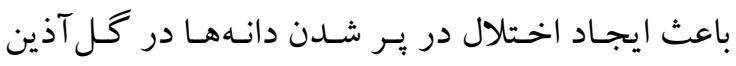

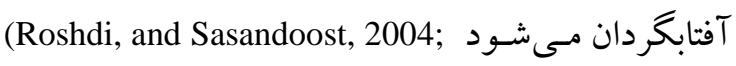
در آزمـايش دانشيان و همككاران Jaleel et al., 2009)

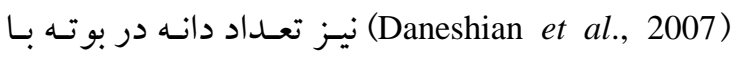
افزايش شدت تنش آبى بهطور معنىدارى كاهش يافت

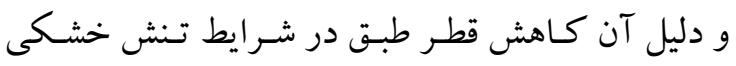

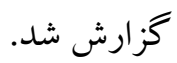
نتايج مقايسه ميانگين ها نشان داد كه وزن هـز ار دانـه در شرايط آبيارى كامل 49 كرم، در شرايط تنش ملايسم و كرم (V/9 درصد كاهش نسبت به آبيـارى كامـل) و

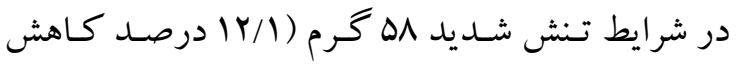

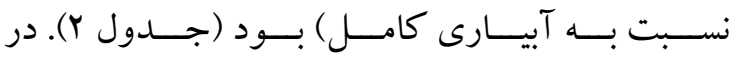

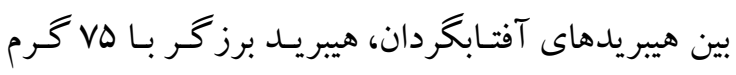

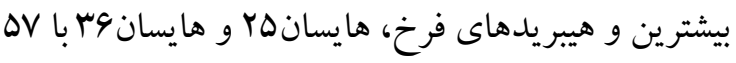

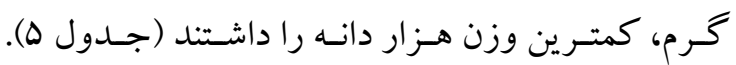

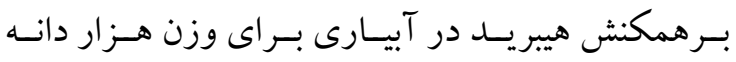

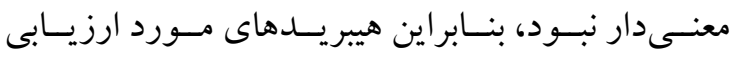

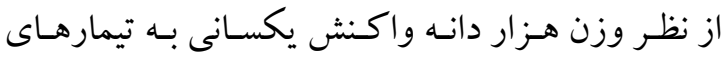
آبيـارى داشـتند. نتــايج آزمـايش نظـامى و همكــاران

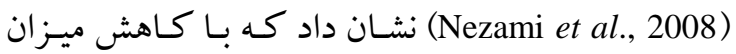

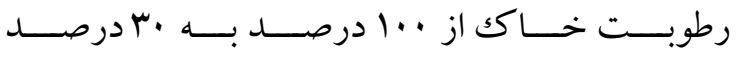

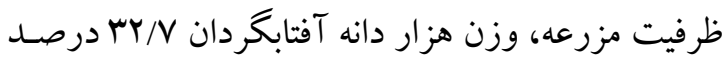

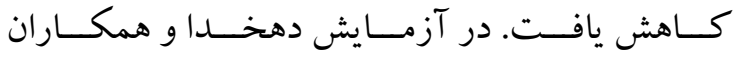
كـاهش وزن هـزار دانسه در (Dehkhoda et al., 2013)

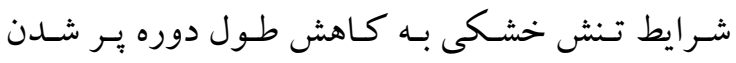

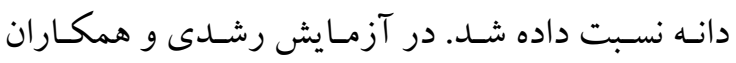
نيز هر دو صفت وزن هزار دانه و (Roshdi et al., 2007) تعداد دانه در طبق در اثر تسنش خشكى كـاهش يافتند.
سال نيز نشـان داد كـه هيبريــدهاى G6*63، يوروفلـور و

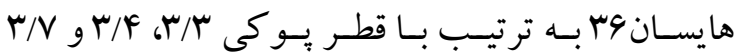

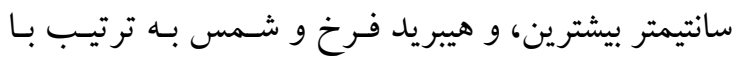

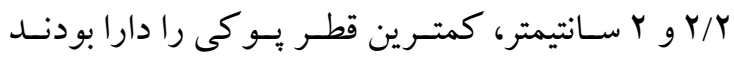
(جدول F). در آزمـايش عباسى سيهجـانى و همكـاران

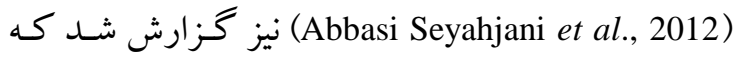

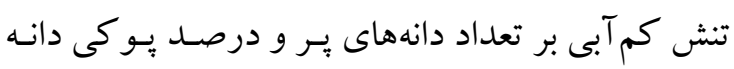

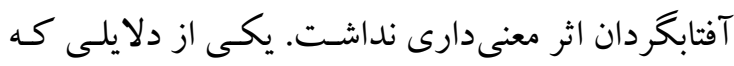

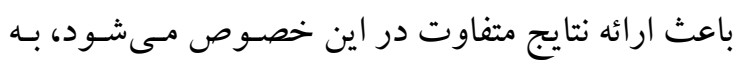

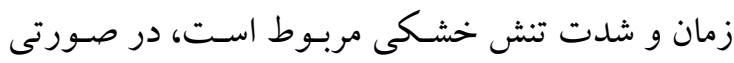
كه تنش خشكى در مراحل اوليه رشد خيـاه آفتابخردان

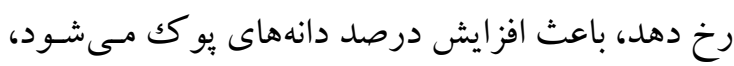

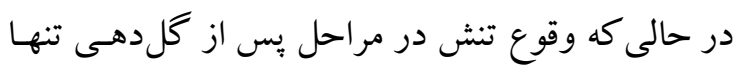

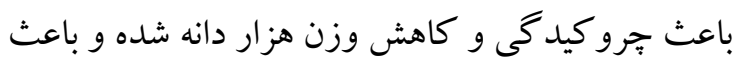

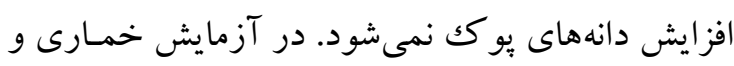

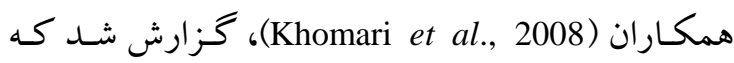
بيشترين درصد يو كى دانه در ارقام آفتابگر دان مربوط به آنه

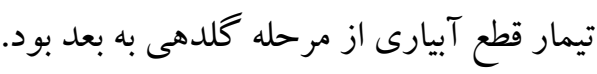

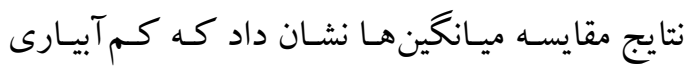
باعـث كـاهش معنسى دار تعـداد دانـهـ در طبـق شـــ، بهطورى كــه در شـــايط آبيـارى كامـل تعـداد دانسه در

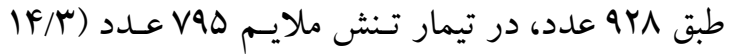

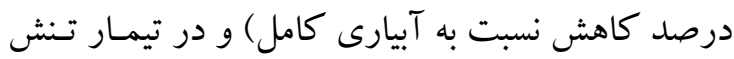
شديد به .94 دانه (YN/9 درصد كاهش نسبت به آبيارى

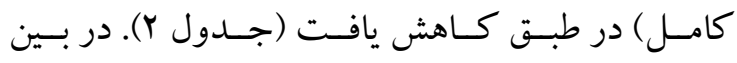

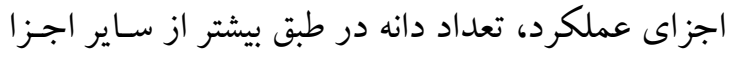

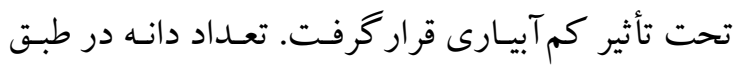

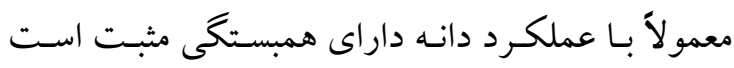
و و كاهش اين جزء عملكـرد (Doddamani et al., 1997) باعث كاهش عملكـرد دانسه مسىشـود. بـر اسـاس نتسايج

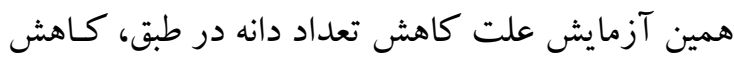

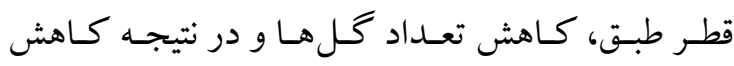

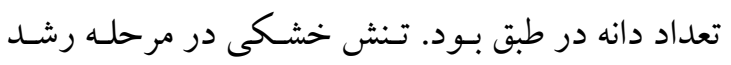

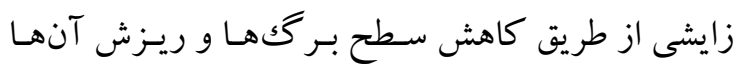




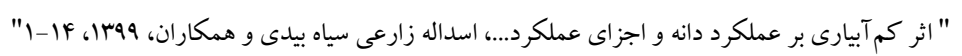

جدول ه- مقايسه ميانگين صفات زراعى هيبريدهاى آفتابخر دان در تيمارهاى آبيارى

Table 5. Mean comparison of agronomic traits of sunflower hybrids in irrigation treatments

\begin{tabular}{|c|c|c|c|c|c|c|c|c|}
\hline \multicolumn{2}{|c|}{$\begin{array}{l}\text { هيبريدهاى آنتابخردان } \\
\text { Sunflower hybrids }\end{array}$} & $\begin{array}{c}\text { روز تا رسيدگ约 } \\
\text { Days to maturity }\end{array}$ & $\begin{array}{c}\text { قطر ساقه diameter (cm) } \\
\text { Stem dian }\end{array}$ & $\begin{array}{c}\text { قطر طبق } \\
\text { Head diameter }(\mathrm{cm})\end{array}$ & $\begin{array}{l}\text { تعداد دانه در طبق } \\
\text { Seed.head }\end{array}$ & $\begin{array}{c}\text { وزن هزار دانه Seed weight (g) } \\
1000 \text { Seeing }\end{array}$ & $\begin{array}{c}\text { روغن دانه } \\
\text { Oil content of seed (\%) }\end{array}$ & $\begin{array}{c}\text { عملكرد دانه } \\
\text { Seed yield }\left(\mathrm{kg} \mathrm{ha}^{-1}\right)\end{array}$ \\
\hline Farrokh & فرخ & 88.2 & 15.4 & 14.9 & 859 & 57.0 & 40.4 & 3780 \\
\hline Shams & شمس & 94.4 & 18.3 & 15.4 & 821 & 61.5 & 40.0 & 3932 \\
\hline Ghasem & قاسم & 88.6 & 17.2 & 14.7 & 801 & 58.8 & 40.2 & 3429 \\
\hline Barzegar & برزگر & 97.8 & 17.3 & 15.8 & 800 & 75.4 & 41.5 & 4091 \\
\hline G5*43 & & 97.4 & 17.9 & 15.6 & 729 & 64.3 & 39.7 & 3687 \\
\hline $\mathrm{G} 6 * 43$ & & 98.2 & 17.8 & 15.4 & 758 & 65.7 & 40.4 & 3782 \\
\hline Hysun 25 & & 88.8 & 16.8 & 14.9 & 799 & 57.4 & 40.9 & 3392 \\
\hline Euroflor & & 92.4 & 17.4 & 15.3 & 801 & 59.4 & 39.8 & 3703 \\
\hline Hysun36 & & 91.0 & 16.5 & 15.8 & 789 & 57.5 & 41.6 & 3465 \\
\hline Azargol & آذر & 98.0 & 16.2 & 15.2 & 800 & 61.1 & 41.4 & 3723 \\
\hline Sumbro & & 84.9 & 17.0 & 15.1 & 818 & 59.6 & 42.5 & 3362 \\
\hline Sirena & & 87.1 & 16.4 & 15.0 & 759 & $62.5 \mathrm{~cd}$ & 41.4 & 3409 \\
\hline $\mathrm{HSD}(\mathrm{p} \leq 0$ & & 9.4 & 3.6 & 2.1 & 202.7 & 18.5 & 2.85 & 857.3 \\
\hline
\end{tabular}


بود. اين موضوع نشان دهنده اين است كـه كـاهش آب

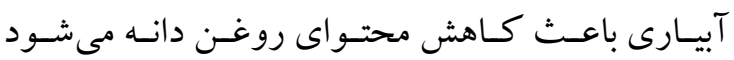

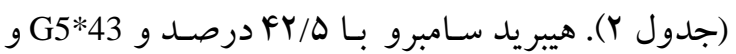

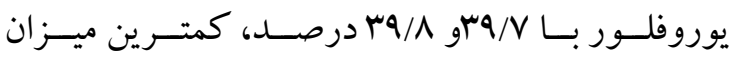

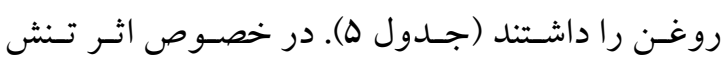

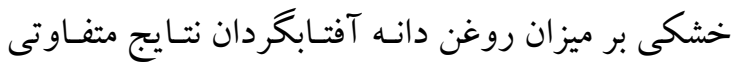

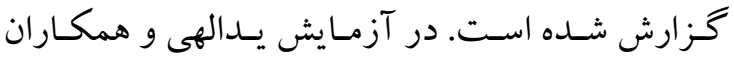
نيز اثر تنش خشكى بــ ميـزان (Yadollahi et al., 2017)

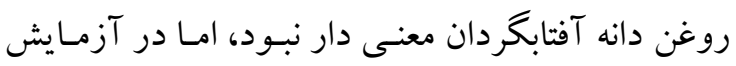
قلى نـز اد و همكـاران (Gholinezhad et al., 2012)

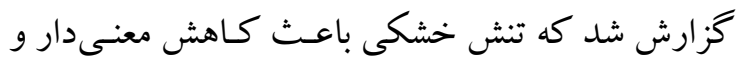
جهار درصدى ميزان روغن دانه نسبت بـه شـرايط بـدون

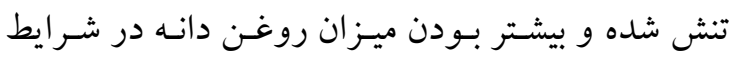
بدون تـنش بـه طـول دوره تبـديل كربوهيـدرات هـا بـهـ روغن و يروتئين ربط داده شد.

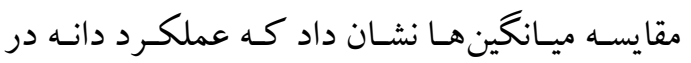

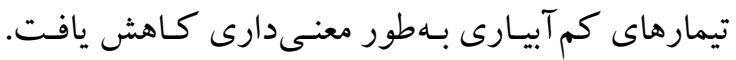

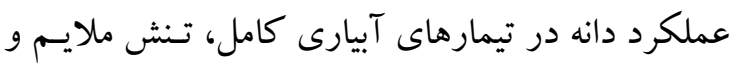

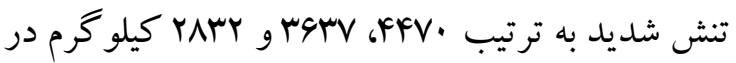

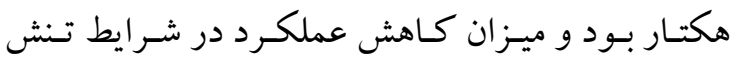
ملايم و شديد نسبت به تيمار آبيارى كامل به ترتيـب 19

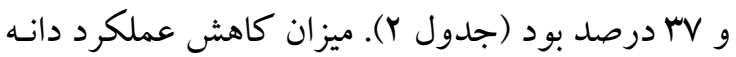

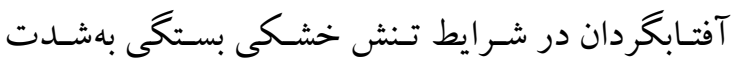

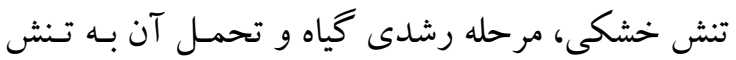

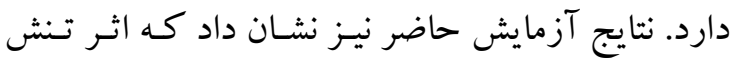

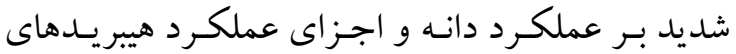

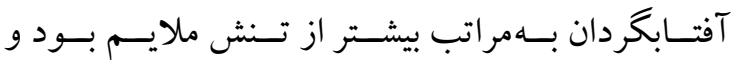

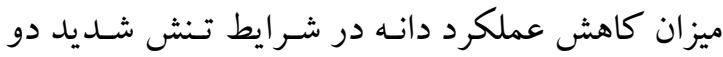
برابـر تـنش ملايسم بـود. در آزمـايش ياتـان و همكــاران نيز بـه كـاهش معنسىدار عملكـرد (Patanè et al., 2017) دانه در شرايط تنش خشكى اشـاره شـده اسـت. در بـين

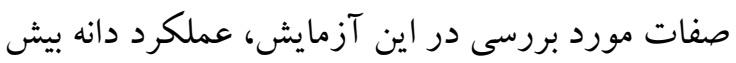

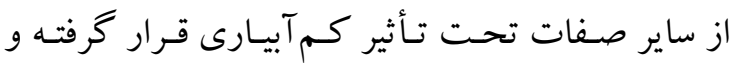
كاهش يافت. كاهش تجمعى اجز اي مهم عملكرد دانس
معمو لاً انتظار مىرود كه با كاهش تعـداد دانه در طبق، به دليل كاهش رقابت براى دريافت مواد فتوسنتزى وزن

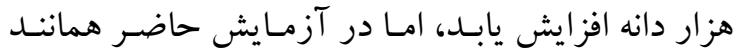
آزمايش رشدى و همكاران (Roshdi et al., 2007) ايـن دمارسن

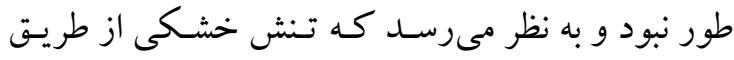
كاهش سطح بركَها و كاهش فتوسنتز جـارى و انتقـال

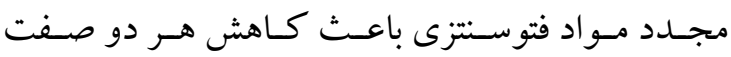
مى شود. در شرايط تنش رطوبتى كاهش وزن دانه بـهويزه در تنش شديد بيشتر بود، زيرا تنش شديد آبـى بـر فتوسـنتز

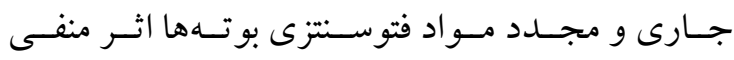

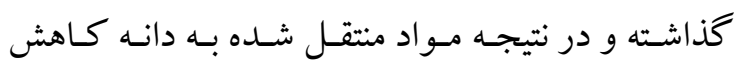

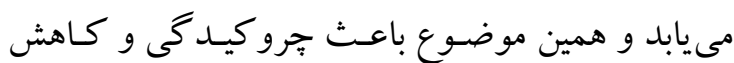

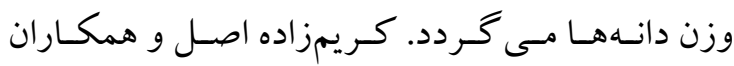
(Karimzade Asl et al., 2003)

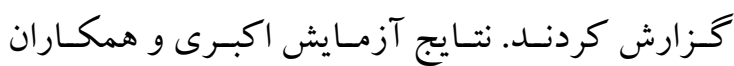

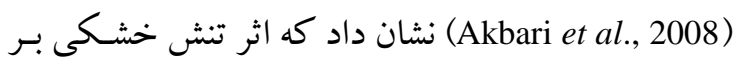

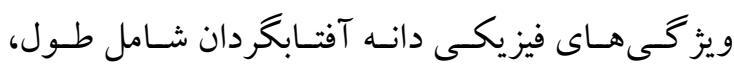
عرض و قطر دانه منفى بود و گززارش شد كـه علد آن آن كاهش توليد مواد فتوسنتى مورد نياز براى برشدن وند دانس

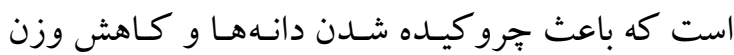
هزار دانه مىشود. اما در آزمايش خمـارى و همكـاران كز ارش شد كه با قطع آبيـارى (Khomari et al., 2008)

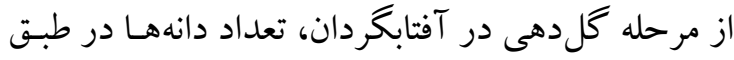

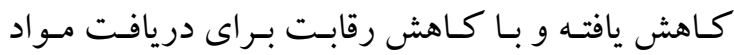

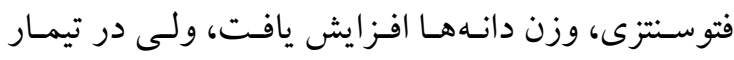

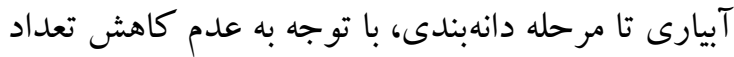

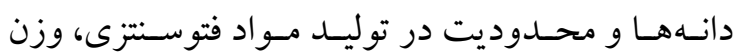

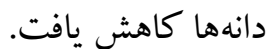
نتايج نشان داد كـه ميزان روغـن دانس دانه در تيمارهـاى

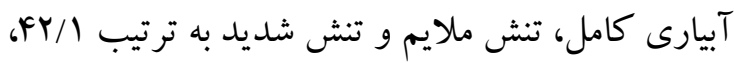

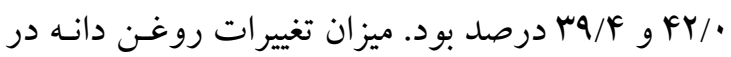

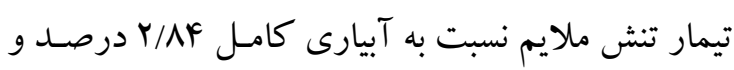

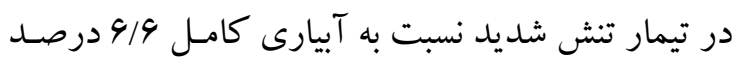


آلل هاى مســول عملكـرد بـالا هستتند قـادر هستـند ايـن

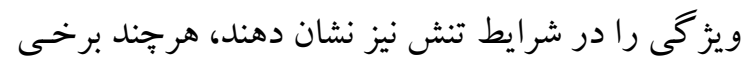

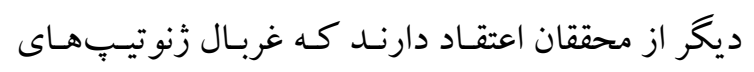
ير محصول آفتابكردان براى شـرايط تسنش خشـكى بايــ در محيط هدف يعنى محيط واجد تـنش خشـكى انجـام كيرد (Rauf, 2008).

\section{نتيجه كيرى}

نتايج آزمايش حاضر نشـان داد كـه عملكـرد دانه و

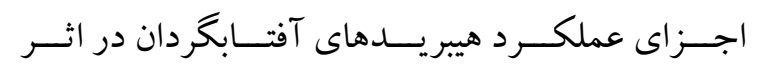

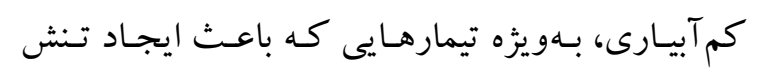

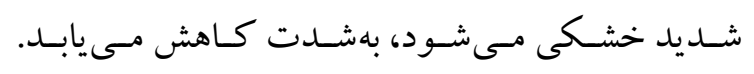

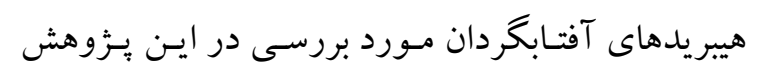
عليرغم اينكه از نظر برخسى خصوصسيات زراعسى داراى

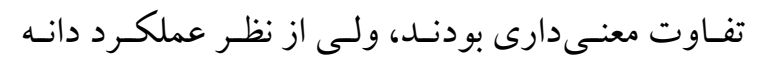
تفــاوت معنـى دارى نداشـتند. بــر ايسن اسـاس از بــين

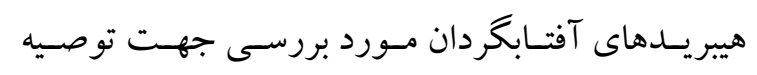

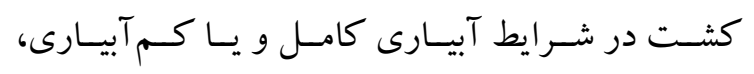
ارجحيت با هيبريدهاى زودرس و ياكو تاه مىباشد.

\section{سياسگز ارى}

بلدينوسـيله از سـردبير محتـرم نشـريه علـوم زراعسى

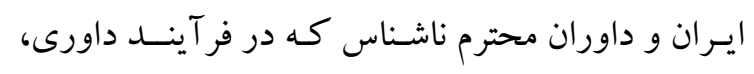
مقاله را به دقت مورد بررسى قرار دادنــد و ييشـــهادهاى خـوبى در راسـتاى ارتقـاى كيفـى مقالـه ارائسه نمودنسـا،

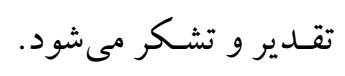

References

\section{References}

Abbasi Seyahjani, E., F. Farahvash, H. Kazemi Arbat and M. Khorshidi Benam. 2012. Effect of drought stress on seed yield and some morpho-physiological traits of sunflower. Environ. Stresses Crop Sci. 5 (2): 190-196. (In Persian with English abstract).

Akbari, Gh. A., H. Jabbari, J. Daneshian, I. Alahdadi and N. Shahbazian. 2008. The Effect of limited irrigation on seed physical characteristics in sunflower hybrids. J. Crop Prod. Proc. 12 (45): 513-523. (In Persian with English abstract). 


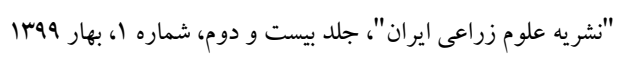

Akcay. S. and N. Dagdelen. 2016. Water use efficiency, yield and yield components of second crop sunflower under deficit irrigation. Turk. J. Field Crops. 21(2): 190-199.

Andrianasolo, F. N., P. Casadebaig, E. Maza, L. Champolivier, P. Maury and P. Debaeke. 2014. Prediction of sunflower grain oil concentration as a function of variety, crop management and environment using statistical models. Eur. J. Agron. 54: 84-96.

Blum, A. 1979. Genetic improvement for drought resistance in crop plants: A case for sorghum. p. 430-445. In: Musell, H. and R. C. Staples (Eds.). Stress Physiology in Crop Plants. John Wiley and Sons, Inc., New York, USA.

Daneshian, J. and H. Jabbari. 2009. Effect of limited irrigation and plant density on morphological characteristics and grain yield in a dwarf sunflower hybrid (CMS26×R103) as second crop. Iran. J. Crop Sci. 10 (40): 377-388. (In Persian with English abstract).

Daneshian, J., H. Jabbari and A. Farokhi. 2007. Sunflower yield and yield components responses to water stress under different densities. Agric. Res. 7 (3): 129 -140. (In Persian with English abstract).

Dehkhoda, A., M. R. Naderidarbaghshahi, A. Rezaei and B. Majdnasiri. 2013. Effect of water deficiency stress on yield and yield component of sunflower cultivars in Isfahan. Int. J. Farming and Allied Sci. 2 (2): 1319-1324.

Doddamani, I. K., S. A. Patil and R. L. Ravikumar. 1997. Relationship autogamy and self fertility with seed yield and yield components in sunflower (Helianthus annuus L.). Helia, 20: 95-102.

Fereres, W., C. Gimenez and J. M. Femandez. 1986. Genetic variability in sunflower cultivars under drought, yield relationships. Aust. J. Agric. Res. 37: 573-582.

Gholinezhad, E., A. Aynaband, A. Hassanzade Ghorthapeh, G. Noormohamadi and I. Bernousi. 2012. Effects of drought stress, nitrogen amounts and plant densities on grain yield, rapidity and period of grain filling in sunflower. J. Sus. Agric. Prod. Sci. 22 (1): 129-143. (In Persian with English abstract).

Hussain, M., Sh. Farooq, W. Hasan, S. Ul-Allah, M. Tanveer, M. Farooq and A. Nawazd. 2018. Drought stress in sunflower: physiological effects and its management through breeding and agronomic alternatives. Agric.Water Manage. 201: 152-166.

Hussain, S., M. Ahmad, S. Ahmad, J. Iqbal, M N. Subhani, S. M. Nadeem and M. Ibrahim. $2013 a$. Improvement of drought tolerance in sunflower (Helianthus annuus L.) by foliar application of abscisic acid and potassium chloride. Pak. J. Nutr. 12 (4): 345-352.

Ibrahim, M. F. M., A. Faisal and S. A. Shehata. 2016. Calcium chloride alleviates water stress in sunflower plants through modifying some physio-biochemical parameters. Am.-Eurasia. J. Agric. Environ. Sci. 16 (4): 677-693.

Jaleel, A. C., P. Manivannan, A. Wahid, M. Farooq, H. J. Al-Juburi, R. Somasundaram and R. Paneerselvam. 2009. Drought stress in plants: a review on morphological characteristics and pigments composition. Int. J. Agric. Biol. 11: 100-105.

Karimzade Asl, K. H., D. Mazaheri and S. A. Peighambari. 2003. Effect of four irrigation intervals on the seed yield and quantitative characteristics of three sunflower cultivars. Iran. J. Agric. Sci. 34 (2): 293-301. (In Persian with English abstract). 


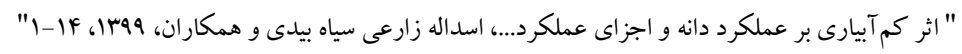

Khan, A., M. Iqbal, I. Ahmad, N. Iqbal and M. Hussain. 2000. Effect of different water stress levels on yield and oil contents of sunflower (Helianthus annuus L.) cultivars. Pak. J. Biol. Sci. 3 (10): 1632-1633.

Khomari, S., K. Ghasemi Golezani, H. Aliari, S. Zehtab Salmasi and A. Dabagh Mohamadi nasab. 2008. Effect of irrigation disruption on phenology and grain yield of three sunflower (Helianthus annuus L.) cultivars in Tabriz. J. Agric. Sci. Natur. Resour. 14(6):1-7. (In Persian with English abstract).

Krizmanić, M., I. Liović, A. Mijić, G. Krizmanić, B. Šimić, T. Duvnjak, M. Bilandžić, R. Marinković, D. Gadžo and A. Markulj. 2012: Effect of environment on quantitative traits of new sunflower hybrids. Sjemenarstvo, 29 (3-4): 121-135.

Mobasser, H. R. and A. Tavassoli. 2013. Effect of water stress on quantitative and qualitative characteristics of yield of sunflower (Helianthus annuus L.). J. Novel Appl. Sci. 2(9): 299-302.

Nezami, A., H. R. Khazaei, Z. Boroumand Rezazadeh and A. Hosseini. 2008. Effects of drought stress and defoliation on sunflower (Helianthus annuus) in controlled conditions. Desert, 12: 99-104.

Ouk, M., F. Shu, F. Ken, B. Jaya, C. Mark and N. Harry. 2003. Routine selection for drought resistance in rain fed lowland rice (Oryza sativa L.) in Cambodia. Proceeding The International Conference on Research on Water in Agriculture, 25-28 November, CARDI, Cambodia.

Patanè, C., S. L. Cosentino and U. Anastasi. 2017. Sowing time and irrigation scheduling effects on seed yield and fatty acids profile of sunflower in semi-arid climate. Int. J. Plant Prod. 11 (1): 17-32.

Pekcan, V., G. Evci, M. L. Yilmaz, AS. Balkan Nalcaiyi, SC. Erdal, N. Cicek, NY. Ekmekci and Y. Kaya. 2016. Drought effects on yield traits of some sunflower inbreds. Agric. Forestry. 61(4): 101-107.

Rauf, S. 2008. Breeding sunflower (Helianthus annuus L.) for drought tolerance. Commun. Biometr. Crop Sci. 3(1): 29-44.

Reddy, A. R., K. V. Chaitanya and M. Vivekanandan. 2004. Drought induced responses of photosynthesis and antioxidant metabolism in higher plants. J. Plant Physiol. 161: 1189-1202.

Robert, G. A., M. Rajasekar and P. Manivannan. 2016. Triazole-induced drought stress amelioration on growth yield, and pigments composition of Helianthus annuus L. (sunflower). Int. Multidiscip. Res. J. 5: 6-15.

Roshdi, M. and R. Sasandoost. 2004. A study of different irrigation levels effect on quantitative and qualitative of sunflower cultivars. Iran. J. Agric. Sci. 36 (5): 1241-1250. (In Persian with English abstract).

Roshdi, M., H. Heydari Sharifabad, G. Noor Mohammadi and F. Darvish. 2007. A Survey on the impact of water deficiency over the yield of sunflower seed cultivar and its components. J. Agric. Sci. 12 (1): 109-122. (In Persian with English abstract).

Tabatabei, S. A., V. Rafieie, E. Shekari and A. Salmani. 2012. Responses of sunflower (Helianthus annuus L.) to deficit irrigate different growth stages. Int. J. Agric. Res. Rev. 2 (5): 624-629.

USDA. 2016. United States Department of Agriculture's National Nutrient Database for Standard Reference.

Yadollahi, P., M. R. Asgharipour, H. Marvane, N. Kheiri and A. Amiri. 2017. The effects of drought stress on grain and oil yield of two cultivars of sunflower. J. Crop Sci. Res. Arid Regions. 1(1): 65-76. (In Persian with English abstract). 
"نشريه علوم زراعى ايران"، جلد بيست و دوم، شماره 1، بهار 1\%9ا

\title{
Effect of deficit irrigation on seed yield and yield components of sunflower (Helianthus Annuus L.) hybrids
}

\author{
Zareei Siahbidi, A., ${ }^{1}$ A. Rezaizad ${ }^{2}$ and J. Daneshian ${ }^{3}$
}

\begin{abstract}
Zareei Siahbidi, A., A. Rezaizad and J. Daneshian. Effect of deficit irrigation on seed yield and yield components of sunflower (Helianthus Annuus L.) hybrids. Iranian Journal of Crop Sciences. 22(1): 1-14. (In Persian).
\end{abstract}

This experiment was conducted to evaluate the effect of deficit irrigation on seed yield and its components of sunflower hybrids, and also identify tolerant hybrids. Twelve sunflower hybrids; Farrokh, Shams, Ghasem, Barzegar, G5 ×43, G6×43, Hysun25, Hysun36, Azargol, Sumbro, Euroflor and Sirena were evaluated under three irrigation treatments; normal irrigation $(60 \mathrm{~mm})$, mild drought stress $(120 \mathrm{~mm})$ and severe drought stress $(180 \mathrm{~mm})$ evaportation from Class A Pan, using split plot arrangements in randomized complete block design with three replications in Islamabad Gharb research station, Iran in 2012 and 2013 cropping seasons. Irrigation treatments were assigned to main plots, and sunflower hybrids were randomized in sub plots. Results of combined analysis of variance showed that irrigation treatments had significant effect on growth duration, stem diameter, head diameter, seed per head, 1000 seed weight and seed yield, but had no significanteffect on seed oil content. Sunflower hybrids were significantly difference for growth duration, 1000 seed weight and seed yield. Interaction effect sunflower hybridxirrigation was not significant for any of measured traits. Mean comparison showed that seed yield of sunflower hybrids was more affected by irrigation treatments than other traits, as average seed yield in normal irrigation, mild drought stress and severe drought stress were 4470, 3637 and 2832 $\mathrm{kg} \mathrm{ha}^{-1}$, respectively. Reduction in seed yield was due to cumulative reduction in yield components such as head diameter, seed per head and 1000 seed weight. Sunflower hybrids were also different for growth duration, plant height, non-filled seed, head diameter, seed per head and 1000 seed weight. Barzegar and Sumbro hybrids had the highest and lowest seed yield (4091 and $3362 \mathrm{~kg} \cdot \mathrm{ha}^{-1}$, respecrively) and the the highest seed oil content was obtaind in Hysun36 hybrid (45.6\%). The results showed that Barzegar hybrid had the higher seed yield in both full irrigation and deficit irrigation conditions, therefore it can be recommended to be grown under these conditions.

Key words: Drought stress, Head diameter, Hybrid, Seed oil content, and Sunflower.

\footnotetext{
Received: February, $2019 \quad$ Accepted: March, 2020

1. Assistant Prof., Field and Horticultural Crops Science Research Department, Kermanshah Agricultural and Natural Resources Research and Education Center, AREEO, Kermanshah, Iran. (Corresponding author)

(Email: azareei46@gmail.com)

2. Associate Prof., Field and Horticultural Crops Science Research Department, Kermanshah Agricultural and Natural Resources Research and Education Center, AREEO, Kermanshah, Iran

3. Profesor, Seed and Plant Improvement Institute, AREEO, Tehran, Iran
} 